\title{
Progressive Union Organizing: The SEIU Justice for Janitors Campaign
}

\author{
Richard W. Hurd and William Rouse \\ COMPETING EXPLANATIONS FOR THE DECLINE IN \\ UNION ORGANIZING SUCCESS
}

Union officials blame their organizing problems on management's increased willingness and ability to resist unionization. They argue that a minefield has been erected for organizers, and that in their zeal to defeat unions, management regularly violates both the spirit and the letter of labor law. Furthermore, the Reagan National Labor Relations Board has reinterpreted the law to facilitate resistance of unions. Because it is more difficult to win, fewer campaigns are initiated. Instead, union resources have been shifted into the political arena in an effort to improve the legal environment (Diamond 1988). Sympathetic industrial relations academics agree, concluding that management suppression represents the "single most powerful explanation for union decline (Fiorito and Maranto 1987: 12)." These efforts have been aided by the Reagan NLRB, whose decisions reflect "a swift ... erosion in the very fabric of the law supporting collective bargaining (Sockell and Delaney 1987: 43)."

Radical analysts reject this explanation. They agree that management aggression has increased, but assert that the passivity of labor leaders committed to business unionism has allowed the attack to succeed. Militant Marxist Kim Moody eschews union efforts to influence the political process, and criticizes the paucity of organizing activity. Unions are portrayed as inattentive to the needs of unorganized workers, pursuing the easy route to membership gain by merging with smaller unions or absorbing independent public employee associations. As a result unions that have added members have done so outside of their traditional base, creating a form of general unionism which lacks clear focus or economic rationale. Revitalization of the labor movement will require rank-and-file insurgency to topple the union bureaucracy, augmented by an aggressive grassroots campaign to organize the unorganized. The focus of this organizing should be on low-wage service workers, most of whom are women and/or minorities. The long-run goal should be the formation of a militant class-conscious labor movement dedicated to rank-and-file democracy (Moody 1988).

In his analysis of unions in decline, Robinson notes that militant Marxists are often so concerned about the social relations between labor and capital that they tend to ignore the role of the state. Their prescription for the emergence of class-based unionism overlooks the mediating role played by the legal environment. A change in tactics with increased militance is not enough to reverse the fortunes of workers and unions. In this context, Robinson is less critical of apparent union indifference to organizing, pointing out that the search for a legislative solution is understandable in terms of political relations (Robinson 1988).

Edwards and Podgursky, while sharing Moody's concern for the failure of business unionism, are less cynical about the potential for the labor movement to respond. They suggest that unions reestablish their pre-World War II image as defenders of social and economic justice, building coalitions with other social movements. Corporate campaigns can be particularly useful as a form of management harassment which can heighten public awareness of class differences (Edwards and Podgursky 1986).

As will become apparent, many of the tactics employed by Justice for Janitors are consistent with the suggestions of radicals. At the same time the experience highlights the potential difficulties posed by the legal system, which creates barriers that even well conceived campaigns are ill equipped to overcome without the financial and institutional support of the union bureaucracy. 


\section{THE SEIU JUSTICE FOR JANITORS CAMPAIGN ${ }^{i}$}

The Justice for Janitors campaign was conceived during a bitter labor dispute with Pittsburgh's Mellon Bank which started late in 1985. Mellon Bank, having just renewed an Service Employees International Union collective-bargaining agreement, replaced their former cleaning contractor with a nonunion company. The new contractor refused to honor the Mellon-SEIU labor accord and was willing to hire only half of Mellon's 80 janitors on a part-time basis with a substantial pay cut and no benefits. Mellon disclaimed any responsibility, stating that the dispute was strictly between the new cleaning contractor and the janitors. In response the SEIU called a strike, filed unfair labor practice charges with the NLRB and began an active media campaign against Mellon. The strike was settled in September 1987 when the NLRB ruled Mellon to be a "co-employer" of the janitors. Mellon subsequently agreed to reinstate janitors under the union contract and to pay $\$ 750,000$ in back wages (Wright 1987).

The Pittsburgh case is typical of the challenges facing the SEIU. Although the eventual victory came with an NLRB ruling, the SEIU developed some basic corporate campaign tactics in the process, gaining community support and heavy media exposure which contributed to substantial public embarrassment for Mellon Bank. These tactics became the foundations of the Justice for Janitors campaign. Although the SEIU continues to file complaints with the NLRB, the union bypasses NLRB certification elections and uses its corporate campaign tactics as leverage in gaining union recognition.

The building services industry is disjointed, localized and very competitive. Large office buildings are often owned by a number of different investors. Furthermore, it is often vague as to who has control of management decisions. The SEIU faces an industry structure of building owners, building management companies and private janitorial subcontractors which allow for the passing on of responsibility.

The building services transformation has resulted in the transition of working conditions. Whereas janitors were previously employed full-time and provided with modest benefits, now janitors work part-time, earn low wages and receive no benefits, while typically cleaning the same amount of office space previously cleaned by full-time janitors (SEIU 1986, 1988). The janitorial work force consists of less educated minority workers, usually women and/or recent immigrants. Since the work is low paying and part-time, most janitors are forced either to work multiple jobs or to depend upon the welfare system to make ends meet. Worker turnover is typically very high.

The increase in part-time work and the high worker turnover have contributed to the SEIU decision to bypass NLRB election procedures. Legal delays of elections can be easily obtained by management and are an especially effective union-avoidance technique where these labor market characteristic are present. Furthermore, successful elections can be subverted by unscrupulous contractors who can simply set up new firms and operate nonunion. Even if the cleaning contractor agrees to bargain with the union, the danger remains that increased wages and benefits will raise costs sufficiently that the unionized cleaning company loses contracts to low wage nonunion competitors.

Faced with these barriers, the SEIU decided to make the building owners the primary target. The SEIU seeks prior agreements from the owners to remain neutral during the organizing drive and to contract with unionized cleaning firms if the organizing is successful. If necessary a corporate campaign is used to pressure the owners to cooperate. Once building owners are neutralized, cleaning contractors are approached and union recognition is requested via a card check. Under this approach, the potentially lengthy NLRB election process is avoided by gaining voluntary recognition from management based on evidence that a majority of workers have signed union authorization cards.

In cities with an existing base of organized janitors, the first phase of the campaign has involved reorganizing previously unionized buildings, negotiating new master labor agreements and reinvigorating the union's local membership. The second phase is organizing the unorganized. In cities which have few organized janitors, the campaign begins with the second, more difficult phase. 
Nonunion janitors' responses have been very positive. In virtually every building targeted in every city with a campaign, an overwhelming majority of the janitors has signed union cards. Furthermore, the janitors are encouraged to act as if they were unionized in their dealings with management. Often an individual is chosen to act as "shop steward," providing information to the SEIU on management actions. One-day strikes in response to management decisions are used to reinforce the solidarity of unorganized workers.

Building owners have typically refused the SEIU neutrality request, triggering the initiation of corporate campaign pressures. The basic goal is embarrassment. Public demonstrations and sit-ins in the targeted buildings are commonly used tactics. In Denver janitors staged a "clean-in" in a building lobby to protest the firing of 13 union janitors (Bulman 1986). In Philadelphia janitors carried giant-sized toothbrushes to protest a job requirement at the Philadelphia Electric Company building where they had to use toothbrushes to clean toilet bowls (Cassedy 1988). In Washington, D.C., supporters went begging for food for the minimum-wage janitors in a building owner's neighborhood (Cohen 1989).

Corporate research is a fundamental aspect of the campaign. The SEIU's national office has published a series of pamphlets which provide financial data on the local office building market, detailing the expenses associated with managing a building and delineating the disparity between building profits and janitorial wages.

Community support for the campaigns has been quite positive. Minority community groups, church groups, immigrant organizations and various coalitions for the working poor have provided energetic vocal support. Government agencies have also been drawn into the crusade. Mayors and city councils have passed resolutions endorsing the campaign's goals. The organizers have also filed complaints of violations with both state and federal Occupational Safety and Health agencies.

Overt management resistance has come primarily from the cleaning contractors. In some cases the SEIU has successfully used NLRB procedures, winning unfair labor practice decisions in response to blatant violations such as firing janitors for supporting the union. The building owners have provided a more elusive target, denying responsibility for the wages and working conditions. They are clearly becoming annoyed, however, as the title of a recent Forbes article indicates - "The JFJ Will Get You If You Don't Watch Out" (Cohen 1989). In some cases, this annoyance has turned into aggression, as building owners have begun to wage legal battles against the SEIU. In Washington, D.C., building owners have obtained court injunctions forbidding union members access to their property.

The Justice for Janitors campaign has experienced some success in increasing union membership and in consolidating wage gains and benefits. Pittsburgh and Denver have completed successful campaigns. In Philadelphia, Los Angeles and San Diego, the consolidation phase has been successfully completed and phase-two organizing of new janitors is underway. Oakland and San Jose are in the early stages of phase one. Atlanta and Washington, D.C., not having the benefit of an established union base among building service employees, continue to campaign for unorganized workers.

\section{TAKING ON JOHN PORTMAN - THE ATLANTA CAMPAIGN}

The Atlanta Justice for Janitors campaign began in March 1987. There are approximately 1,300 janitors, predominantly less educated black women, in major office buildings in downtown Atlanta. The majority work part-time and are paid just above the minimum wage with few benefits. Organizing activity follows the general pattern described above. The janitors sign union cards and are encouraged to act as if they are unionized. Janitors have responded enthusiastically with 900 of the 1,300 signing cards and with strong support for several one-day strikes at key buildings.

Public demonstrations in the headquarters buildings of targeted companies have been used to bring the campaign's issues to the public. Janitors and community supporters have peacefully demonstrated in the lobbies of the Coca-Cola, CNN and Georgia-Pacific buildings. SEIU organizers have also filed OSHA complaints concerning lack of ventilation and inadequate training in the handling of 
cleaning chemicals. Strong community support has been provided by a variety of groups, including ACORN and the SCLC. The City Council has proclaimed their agreement with the campaign's goals, and Mayor Andrew Young has actively mediated talks between the Justice for Janitors' staff and building owners. Both Jesse Jackson and Coretta Scott King have issued sympathetic statements.

While most building owners have attempted to remain aloof, Atlanta's largest real estate developer, John Portman, has staged an aggressive counterattack. The Portman Companies own over \$1 billion worth of real estate in Atlanta, including the Peachtree Center, the Westin Peachtree Plaza, the Merchandise Mart and the Marriott Marquis. Security guards have denied union representatives access to these properties, and the Portman Companies have leveled a broad-ranging legal barrage in an attempt to undermine the organizing efforts. This bitter resistance and Portman's high visibility offered an obvious target for the SEIU. A corporate campaign was initiated against the Portman Companies, contrasting the $\$ 3.50$ hourly wage of the building janitors with John Portman's estimated personal net worth of $\$ 200$ to $\$ 300$ million. The campaign has expanded into a national boycott sanctioned by the AFL-CIO. In addition to the Atlanta properties, the AFL-ClO boycott includes the Westin Bonaventure in Los Angeles, and the Portman Hotel, the Embarcadero Center and the Fashion Center in San Francisco.

To date, the Portman Companies' aggressive legal resistance has prevailed. In 1987 and 1988 they obtained a series of injunctions in state courts which restrict union access to their major properties. The injunctions also limit activity on the adjoining sidewalks, forbidding shouting, the use of bullhorns and gathering in groups of six or more. The SEIU responded with an unfair labor practice complaint to the NLRB, claiming that they were being denied access to employees for the purpose of organizing. The NLRB General Counsel concurred that the employees' right to organize was being violated. However, on the eve of a hearing on the complaint, the Reagan NLRB issued a decision in another case broadening the definition of instances where property rights can limit the union's right to access. Referring to this decision, the judge ruled against the union. The SEIU has appealed.

Meanwhile, the Portman Companies have filed a countersuit with the NLRB, claiming that the nationwide boycott of Portman properties is an illegal secondary boycott. The charge is based on the premise that the janitors are not employed by Portman but by the cleaning contractors. Portman is also seeking $\$ 435,000$ in damages for boycott activity conducted in conjunction with the 1988 Democratic National Convention. In order to respond, the SEIU legal staff has been forced to devote an inordinate

amount of time to the case, with from one to three of the six-member staff involved at various stages. In addition two Atlanta law firms have been retained, one to assist with state court proceedings, the other with the NLRB cases.

\section{ANALYSIS AND CONCLUSIONS}

Management's combative efforts to resist Justice for Janitors is consistent with the union movement's rationalization for reduced organizing success. The ability of the SEIU to overcome this resistance, due in part to their strategy of bypassing NLRB election procedures, offers other unions an example of how to respond to the hostile environment. Nonetheless, the ability of management to erect seemingly insurmountable legal hurdles in Atlanta demonstrates why unions persist in their attention to labor law reform.

Consistent with the prescription offered by radicals, Justice for Janitors demonstrates that an aggressive organizing campaign can succeed. The campaign does indeed focus on low-wage service workers, most of whom we are women and/or minorities. Furthermore, in this effort the SEIU has returned to its original blue-collar membership base (until 1963 the union's name was the Building Service Employees International Union). Coalitions with other social movements have been instrumental to the campaign's successes, as has the effective construction of an image associated with the defense of justice for workers being oppressed by the excesses of management. The harassment of real estate moguls provides a useful example of the potential benefits of corporate campaigns. 
Tactically, then, Justice for Janitors has paralleled the course approved by Marxists who seek a progressive class-oriented labor movement. However, it is doubtful that the campaign could have survived without the organizing, research and legal sustenance provided by the SEIU, an influential member of the entrenched labor bureaucracy. Although the SEIU has stemmed membership decline among building service employees and even added several thousand new members, it is unlikely that Justice for Janitors has been cost-effective. The SEIU's ability to subsidize the organizing is no doubt a result of its growth through affiliation of public employee associations. Ironically, the general unionism criticized by Moody has provided the necessary financial resources for the type of aggressive organizing he promotes. In cities where the SEIU already has a membership base among building service employees, assistance from the national union has been significant. In Atlanta, a city where unions are relatively weak, this support is essential both to withstand the legal barrage coordinated by the Portman Companies and to garner the forces necessary to conduct a successful corporate campaign.

Justice for Janitors illustrates Robinson's thesis. Organizing the unorganized, building coalitions and waging corporate campaigns are all critical elements for promoting a progressive labor movement. But political and legal conditions can and will interfere. Thus, the attention of organized labor to labor law reform is also important. The long-run goal of a militant class-conscious labor movement is laudable, but isolated militance that ultimately fails is self-defeating. For the present, the best hope of workers is to respond to the power of corporations by taking advantage of the countervailing power offered by established unions.

\section{REFERENCES}

Bulman, Philip. 1986. Clean-in Protests Firing of Janitors. Denver Post November 7: B-8.

Cassedy, Ellen. 1988. Justice for Janitors: No More Toothbrushes for PECO's Toilets. Philadelphia Daily News March 17.

Cohen, John. 1989. The JFJ Will Get You If You Don't Watch Out Forbes October 23: 390.

Diamond, Virginia. 1988. AFL-CIO, Department of Organization and Field Services, Washington, D.C. Interview. July $12,1988$.

Edwards, Richard and Michael Podgursky. 1986. The Unraveling Accord. In, Unions in Crises and Beyond, Edwards, Garonna and Todtling (eds.). pp. 14-60. Dover, Massachusetts: Auburn House.

Fiorito, Jack, and Cheryl L Maranto. 1987. The Contemporary Decline of Union Strength. Contemporary Policy Issues. 5 (4): 12-27.

Moody, Kim. 1988. An Injury to All: The Decline of American Unionism. New York: Verso.

Robinson, J. Gregg. 1988. American Unions in Decline: Problems and Prospects. Critical Sociology 15(1): 33-56.

Service Employees International Union. 1986. Justice for Janitors: The Real Story Behind Commercial Real Estate in Denver. Denver SEIU Local 105.

. 1988. ,4 Tale of Two Cities: Poverty Amid Plenty in D.Cs Office Buildings. Washington, D.C: SEIU Local 525.

Sockell, Donna, and John Thomas Delaney. 1987. Union Organizing and the Reagan NLRB. Contemporary Policy Issues 5 (4):33-56.

Wright, Rob. 1987. Janitors at Bank Buildings Receive Back Pay in Labor Disputes. American Banker 152 (October 9): 40.

\footnotetext{
'This section is based on interviews with SEIU representatives except where noted. The authors will provide a copy of the interview schedule and a complete list of those interviewed on request
} 